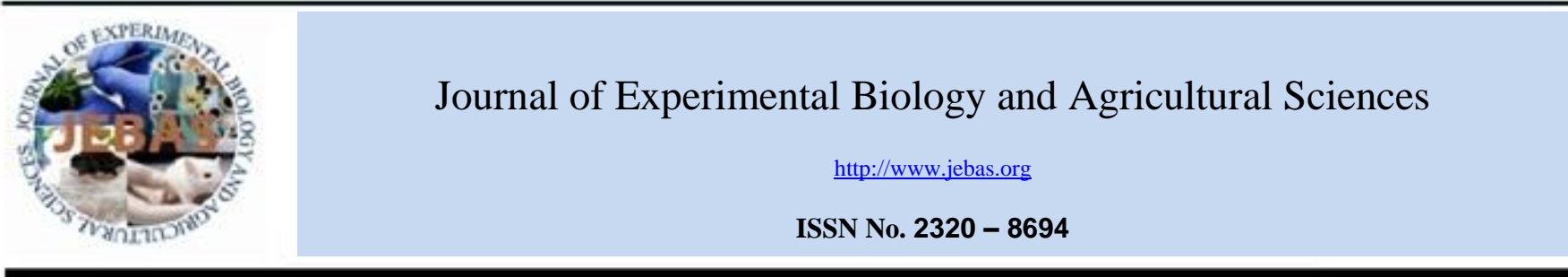

\title{
TECHNICAL CHARACTERISTICS AND CONSTRUCTION FEATURES OF MEAT GRINDERS
}

\section{Yermek Abilmazhinov ${ }^{1}$, Galiya Abdilova ${ }^{1}$, Maksim Rebezov $^{2,3,4}$, Rustem Zalilov $^{5}$, Anton Nesterenko ${ }^{6}$, Mars Khayrullin ${ }^{7}$, Larisa Morozova ${ }^{8}$, Ivan Mikolaychik ${ }^{8}$, Evgeny Ponomarev ${ }^{7}$, Dmitriy Kulikov ${ }^{7}$}

\author{
${ }^{1}$ Shakarim University of Semey, Semey, Kazakhstan \\ ${ }^{2}$ V.M. Gorbatov Federal Research Center for Food Systems of Russian Academy of Sciences, Moscow, Russian Federation \\ ${ }^{3}$ Prokhorov General Physics Institute of the Russian Academy of Science, Moscow, Russian Federation \\ ${ }^{4}$ Moscow State University of Food Production, Moscow, Russian Federation \\ ${ }^{5}$ Nosov Magnitogorsk State Technical University, Magnitogorsk, Chelyabinsk region, Russian Federation \\ ${ }^{6}$ Kuban State Agrarian University, Krasnodar, Russian Federation \\ ${ }^{7}$ K.G. Razumovsky Moscow State University of technologies and management (the First Cossack University), Moscow, Russian Federation. \\ ${ }^{8}$ Kurgan State Agricultural Academy by T.S. Maltsev, Kurgan, Russian Federation (Lesnikovo village, Ketovsky district, Kurgan region, Russian Federation
}

Received - September 25, 2020; Revision - November 16, 2020; Accepted - December 14, 2020

Available Online December 15, 2020

DOI: http://dx.doi.org/ 10.18006/2020.8(Spl-2-AABAS).S361.S367

\section{KEYWORDS}

Meat grinder

Technical characteristics

Construction

Production capacity

\begin{abstract}
Most of the technological operations for the production of meat products are mechanised and carried out using specially designed equipment, including meat grinders. This paper reviews meat grinders of different design and performance, used in both household and industrial applications. The technical characteristics, construction and operating principle of the meat grinder are described.
\end{abstract}

* Corresponding author

E-mail: almihailov@bk.ru (Alexander Loenidovich Mikhailov)

Peer review under responsibility of Journal of Experimental Biology and Agricultural Sciences.

Production and Hosting by Horizon Publisher India [HPI] (http://www.horizonpublisherindia.in/).

All rights reserved.
All the articles published by Journal of Experimental Biology and Agricultural Sciences are licensed under a Creative Commons Attribution-NonCommercial 4.0 International License Based on a work at www.jebas.org.

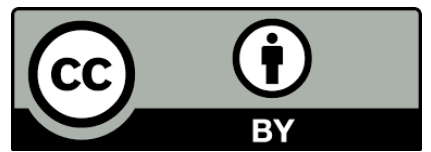




\section{Introduction}

For the modern meat-processing enterprises the problem of the further improvement of technological processes and the appropriate equipment for the reduction of its power capacity, losses of raw materials, increase of productivity, improvement of quality of manufactured products is still relevant (Uriev \& Taleisnik, 1985). The grinding machines for meat and meat products comprise about half of all operating equipment in meat industry. The most common machine for primary grinding of raw meat is the meat grinder. The meat grinder is designed for grinding meat, which is usually equipped with a special set of cutter plates with different diameters to obtain minced meat of different consistency that is used for different types of semi-finished products (Mustafayeva et al., 2016; Kabulov et al., 2019). The meat grinders are available in floor and table models, and its depending on the design of the meat grinder.

The industrial meat grinder consists of a hopper where the piece of meat is supplied, auger or system of augers and a cutting mechanism which consists of movable knives and fixed plates. The augers transport the meat to the cutting mechanism of the grinder, which is a set of fixed plates and rotating knives. Depending on the purpose of the produced minced meat, the cutter plates are available with a whole diameter varying from 3 to $25 \mathrm{~mm}$, which allows to change the texture of the minced meat (Bakieva et al., 2019). The meat grinders differ in capacity, plate diameter and the processed raw material. Depending on the productivity, meat grinders are divided into three groups viz., household - productivity up to $30 \mathrm{~kg} / \mathrm{h}$, catering enterprises productivity $30-1000 \mathrm{~kg} / \mathrm{h}$, and industrial - productivity over $1000 \mathrm{~kg} / \mathrm{h}$ (Kurochkin \& Lyashenko, 2001).

\section{Determining meat grinder capacity}

The meat grinder capacity is calculated by the following formula
$(\mathrm{kN})$ :

$$
Q=F_{0} * v_{0} * \rho * \varphi
$$

Where $F_{0}$ - total area of holes in the first cutter plate which is closest to the auger, $\mathrm{m}^{2} ; \mathrm{v}_{0}$-the speed of meat moving through the hole of the first cutter plate, $\mathrm{m} / \mathrm{s} ; \rho$-product density, $\mathrm{kg} / \mathrm{m}^{3} ; \varphi-$ the coefficient of use of the hole area of the first cutter plate $(\varphi=$ $0.7 \ldots 0.8)$.

Meanwhile

$$
F_{0}=\frac{\pi d_{0}^{2}}{4} \cdot z_{0}
$$

Where $d_{0}$ - hole diameter, $\mathrm{m}$; Zo - number of holes of the cutter plate, pcs. Speed $v_{0}$ can be calculated as the speed of nut. Movement relative to the screw along its axis is calculated by the following formula $(\mathrm{m} / \mathrm{s})$,

$$
v_{0}=\frac{\pi n}{60}\left(r_{H}+r_{B}\right) \operatorname{tg} \beta_{P} K_{B}
$$

Where $n$ - auger rotation speed, min- $1 ; r_{\mathrm{H}}$ and $r_{B}$ - the external and internal radii of the last coil of the auger, $\mathrm{m}$, respectively; $K_{B}$ - the coefficient of volume supply of the product, which is calculated by the formula:

$$
K_{B}=\frac{\omega-\omega_{\text {пр }}}{\omega}
$$

Where $\omega$-auger angular speed, $\mathrm{rad} / \mathrm{s} ; \omega_{n p}$ - product angular speed, $\mathrm{rad} / \mathrm{s}\left(K_{B}=0.35 \ldots 0.4\right)$. (Elkhina \& Botov, 2010; Muratzhankyzy et al., 2018).

\section{Features of different meat grinders constructions}

Matkin \& Sapunkova (2010) proposed the design of an upgraded household electric meat grinder (Figure 1), which includes an

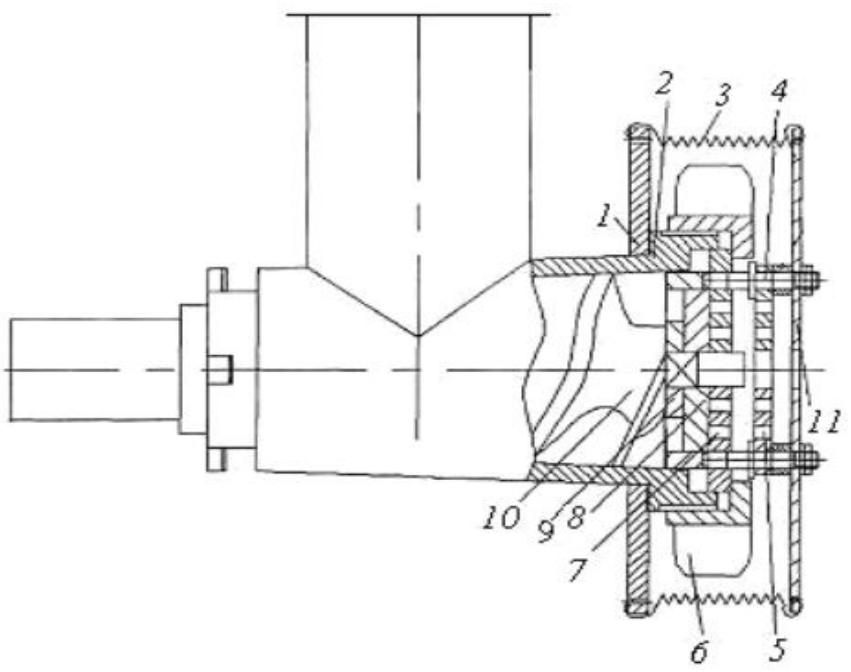

Figure 1 General view of the working body of the modified electric grinder: 1 - clamp; 2 - housing; 3 - spring; 4 - bracket; 5 - second stage plate; 6 - tie ring; 7 - first stage plate; 8 - knife; 9 - cam; 10 - auger; 11 - ring 
electric drive, a working body and a vibrating nozzle. Inside the housing (2) of the meat grinder there is a feed auger (10), which is attached to the motor and receives its rotation. At the output end of the feed auger shaft there is a knife (8) and a fixed plate of the first stage (7). The tight fit of the cutting surface of the knife and the edge of the plate is provided by the tightening ring (6). In the gap between the inner surface of the housing (2) and the blades of the cutting surface of the knife (8) at the output end of the shaft of the auger is installed hardened ring (cam) (9) with an intermittent surface.

The authors of the patent (Patent RU 2479352 C1. 2013) developed a construction of meat grinder. The meat grinder contains a casing with a clamp and a removable handle for screw rotation. The case contains a hollow auger with a movable knife. Inside the screw there is a shaft on one end of which there is an output plate with the possibility of rotation. Between the auger and the shaft is installed kinematic transmission, consisting of several spur gears, main and intermediate, providing rotation of the auger with a movable knife in one direction, and the output plate - in the opposite direction. The handle is designed with the possibility of mounting both on the shaft end and on the shaft of intermediate gears. The invention provides the most favorable modes of grinding, regardless of product hardness.

\subsection{Meat grinders MIM-300 and MIM-600 (Belarus)}

These two are designed for grinding meat and fish for mincing, regrinding of cutlet mass and stuffing sausages at catering enterprises (http://beltorgmash.com/product/myasorubki-mim-300i-mim-600).

Operation of the meat grinder: The meat grinder consists of an aluminium housing in which the auger rotates a clamping nut, twosided knives, a set of cutter plates, a stop ring and a cutter knife.

The housing is fastened with threaded clamps. Above the filling opening there is a fixed fuse that prevents the operator's hand from getting into the meat grinder auger. Meat or fish is cleaned of bones and cut into pieces not exceeding $0.1 \mathrm{~kg}$. The recommended temperature of the processed product should be $(8 \pm 2){ }^{\circ} \mathrm{C}$. Connective tissues and tendons are removed from the processed product. The processed product is fed to the neck of the meat grinder body and then pushed towards the rotating auger. The product conveyed by the auger goes through a set of cutting tools. The meat grinder is equipped with a set of cutter plates with holes of different sizes to obtain minced meat of different degrees of cutting. The plates are mounted in the meat grinder body and held back from turning by a cotter pin.

In the working conditions, Akimov et al. (2001) described a construction of the meat-bone grinder. The unit has a body with a loading hopper. Inside the body there is a screw with variable pitch between coils. The last coil has holes drilled in it. Pre-cut meat is loaded into a hopper, from which it is fed to the chopping bodies by the auger. The pieces of meat, differing in volume and weight, are partially processed with three-blade knives and squeezed out through the plates. A portion of the mass is pressed into the holes and further crushed by the cutting edge, then caught again by the auger coils and fed to the three-blade knives. The machine delivers the product evenly to the shredding bodies, which increases the reliability of its operation.

\subsection{The BRIZ Meat Grinder}

It is with special auger chamber design with spiral rails and variable auger pitch ensures optimal product consistency and the necessary pressure on the knives for the best cutting conditions even for low-grade meat. The sabre-shaped cutting edge of the knife eliminates impact on the product and, due to the longer cutting length, improves the processing quality. Two steel plates with 4.5 and $7 \mathrm{~mm}$ diameter holes ensure the desired consistency of the minced meat. The breakable adapter is the most economical motor protection against the auger jamming (https://www.mobilluck.com.ua/katalog/meat/briz/briz-EMS-

30_160_M11_04-108767.html).

\subsection{The VRD-125 and VRD-200 meat grinders}

The VRD-125 and VRD-200 meat grinders (LLC MILA-M, Russia) are designed to grind frozen meat pieces not exceeding 0.2 $\mathrm{kg}$ or chilled boneless, trimmed meat, meat by-products, backfat and other raw materials, mass of pieces not exceeding $0.35 \mathrm{~kg}$, as well as meal in raw, cooked, blanched form for the production of cooked, raw smoked and semi-smoked sausages, frankfurters, chopped semi-finished products, culinary products, etc. (Table 2). The construction provides for quick disassembly and assembly of the grinding mechanism. It ensures the even flow of meat through the cutting unit. At the same time, it eliminates fat clogging and heating of meat products. It consists of the body, drive, two grinding mechanisms (auger), set of replaceable plates for different grinding ratio, output nozzle, pressure ring, control unit. The parts and assemblies in contact with the product are made of stainless steel (https://euro-pack.ru/volchok-vrd-125a).

\subsection{Industrial Meat Grinder B-132-114}

The industrial meat chopper with productivity not less than 1000 $\mathrm{kg} /$ hour is used for grinding boneless meat for the purpose of obtaining minced meat. Grinder is suitable for grinding of fresh and chilled meat not less than minus $2^{\circ} \mathrm{C}$ and to obtain minced meat from beef, pork, poultry in the production of sausages and other meat products. It can also be used for grinding other products with similar consistency. Meat or other raw materials are loaded into a 
Table 1 Main technical characteristics of the two meat grinder (MIM-300 \& MIM 600)

\begin{tabular}{|ccc|}
\hline Name of parameter & MIM-300 & MIM-600 \\
\hline Technical performance $(\mathrm{kg} / \mathrm{h})$ & 300 & 600 \\
\hline Rated power consumption $(\mathrm{kW})$ & 1.90 & 2.71 \\
\hline Motorpower $(\mathrm{kW})$ & 1.5 & 2.2 \\
\hline The power supply: & 380 & \\
rated voltage (V) & 50 & 765 \\
\hline rated current frequency (Hz) & 250 & 400 \\
\hline Augerrotation speed (rpm) & 680 & 540 \\
\hline Overall dimensions, mm, no more than \\
length & 400 & 55 \\
\hline width & 460 & \\
\hline height & 42 & \\
\hline
\end{tabular}

Table 2 - Technical specification of the meat-grinder VRD-125 and VRD-200

\begin{tabular}{|c|cc|}
\hline Name of parameter & VRD-125 & VRD-200 \\
\hline Outer diameter of the cutter plate $(\mathrm{mm})$ & 125 & 200 \\
\hline Technical performance $(\mathrm{kg} / \mathrm{h})$ & 2000 & 2500 \\
\hline Motorpower $(\mathrm{kW})$ & 15 & 15 \\
\hline Overall dimensions $(\mathrm{mm})$ & $1340 \times 1070 \times 1260$ & 550 \\
\hline Weight, $\mathrm{kg}$, nomore & 500 & $1070 \times 1260$ \\
\hline
\end{tabular}

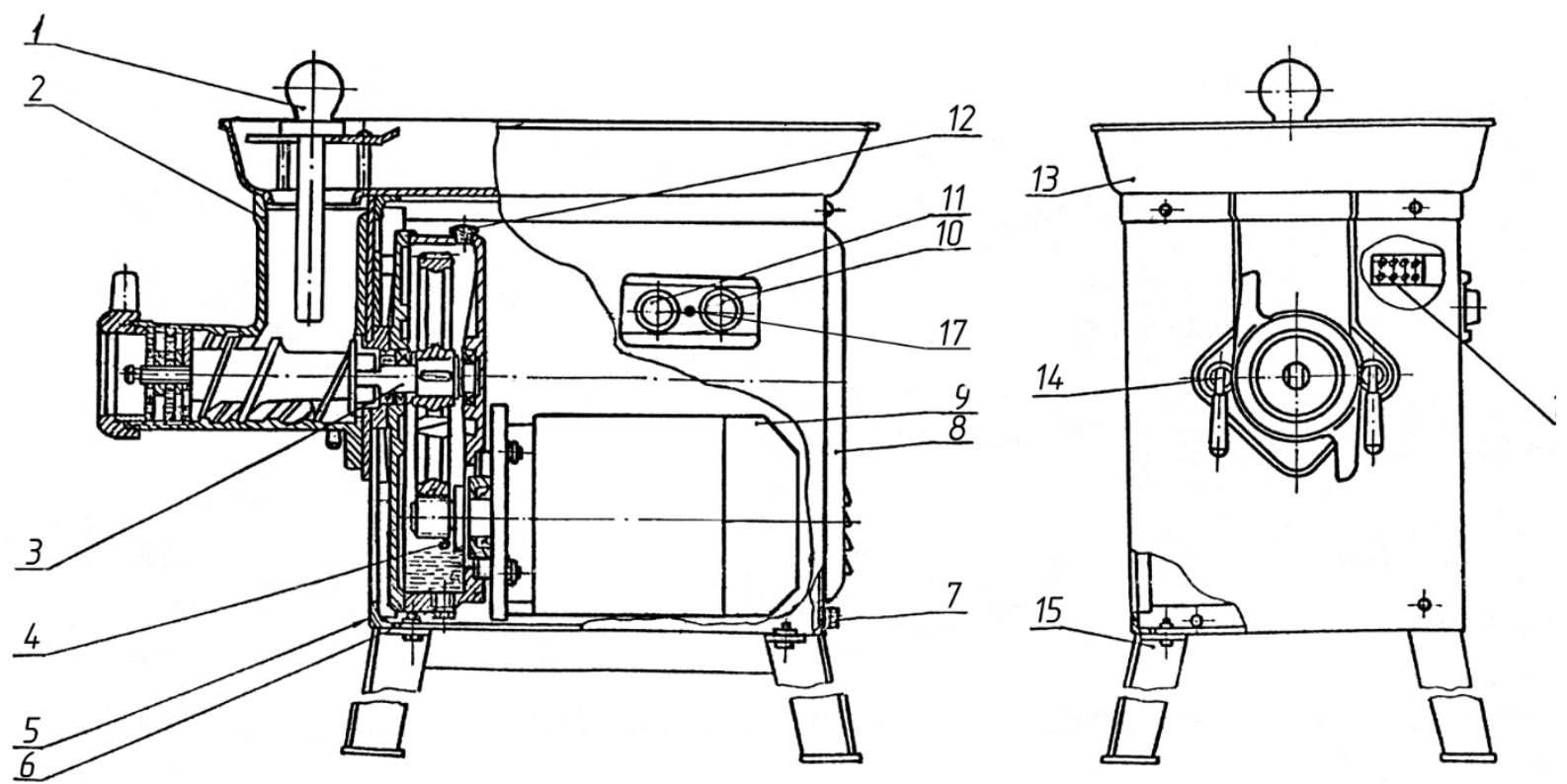

Figure 2 - The meat grinder: 1- the pusher; 2- the meat grinder; 3- shaft drive; 4- oil level control hole; 5- front trim; 6- drainage plug; 7equipotential clamp; 8- rear trim; 9- motor; 10 - "run" button; 11 - "stop" button; 12 - tap; 13 - safety cup; 14 - clamp; 15 - support; 16 clamp block; 17 - indicator 
receiving hopper with a hopper capacity of at least 100 litres. Under its own weight, the meat is fed into the auger. For the safety of the operating personnel, the upper part of the hopper is protected by a hinged grid with an interlock and an open sensor. In the lower part of the hopper the meat is captured by a auger and fed to the cutting mechanism for further grinding. It has a reversal mode, allowing the auger to rotate in the opposite direction if necessary in order to return the product residue from the cutting block back to the hopper neck. The knife block consists of a receiving plate, two knives with an intermediate plate and an output plate. The grinding degree of the product is from $3 \mathrm{~mm}$. The grinder is completely made of stainless steel, including the frame, trim, folding grate, cutting mechanism and fully meets the requirements of food production. The grinder is installed on independently heightadjustable supports, which allows the grinder to be accurately positioned horizontally to avoid vibrations during operation (http://tsib.agroserver.ru/tovari/1025448.htm).

The meat grinder auger is made of high-strength food-grade stainless steel and ensures a continuous supply of minced meat to the cutting mechanism. The motor-reducer with power of $5.5 \mathrm{~kW}$ provides productivity of the grinder at least $1000 \mathrm{~kg} /$ hour (Table 3).

\subsection{Meat grinder K7-FVP-160-2}

This meat grinder is designed for medium and fine grinding of the meat raw materials (Figure 3). It consists of four main mechanisms: feeding and cutting mechanism (2), drive and frame on which all assembly units, parts, electric motor (9) and starting electric apparatus are mounted. The grinder also includes a booster plate (1), knife shaft (3), single-coil blade (5), wedge transmission (8) of the knife shaft, platform (10) for sanitary treatment, tray (11) and tubular nozzle (12) (https://food-mechanics.ru/?p=595). Feeding mechanism includes hopper (6) and augers (4). The cutting mechanism consists of a booster plate (1), an outlet cutter plate (2), knives (3), an intermediate plate (4) and a receiving plate (5), and a cylinder with inner ribs and a wheel nut with a tubular attachment. The knives are made of two parts and have curved teeth, in between which there are channels for the product. The blade rotation speed $\left(8.3 \mathrm{~s}^{-1}\right)$ is higher than that of the auger $\left(3.3 \mathrm{~s}^{-1}\right)$.

This is achieved by the fact that the shaft that drives the blade rotation goes inside the working auger and has its own drive. The auger has hollows at the feeding point for filling and the hopper underneath the auger has cut-off fins. This design ensures a uniform and uninterrupted flow of product into the operating zone.

The number of spiral ribs is more than twice the number of ribs on the side of the feed hopper, which eliminates the return of the product to the hopper. The $8 \mathrm{~mm}$ thick output plate is pressed by a rigid support with radial sharpened ribs. The design of this support allows the use of plates up to $3.0 \mathrm{~mm}$ thick. The drive consists of an electric motor (9), a spur gearbox and a V-belt gearbox (7).
Table 3 - Technical specification of the meat-grinder B-132-114 Nameofparameter Value

\begin{tabular}{|ll|}
\hline \multicolumn{1}{|c|}{ Nameofparameter } & \multicolumn{1}{c|}{ Value } \\
\hline Technical performance $(\mathrm{kg} / \mathrm{h})$ & 114 \\
\hline Outer diameter of the cutter plate $(\mathrm{mm})$ & $3 ; 5$ \\
\hline Diameter of holes of cutter plate $(\mathrm{mm})$ & 100 \\
\hline Hopper volume, l, not less & 280 \\
\hline Augerrotation speed, rpm & $(380 \pm 10 \%)$ \\
\hline Three-phase supply voltage, V 3N & 5.5 \\
\hline Motorpower $(\mathrm{kW})$ & $950 \times 800 \times 1300$ \\
\hline Overall dimensions $(\mathrm{mm})$ & 170 \\
\hline Weight, kg, nomore & \\
\hline
\end{tabular}

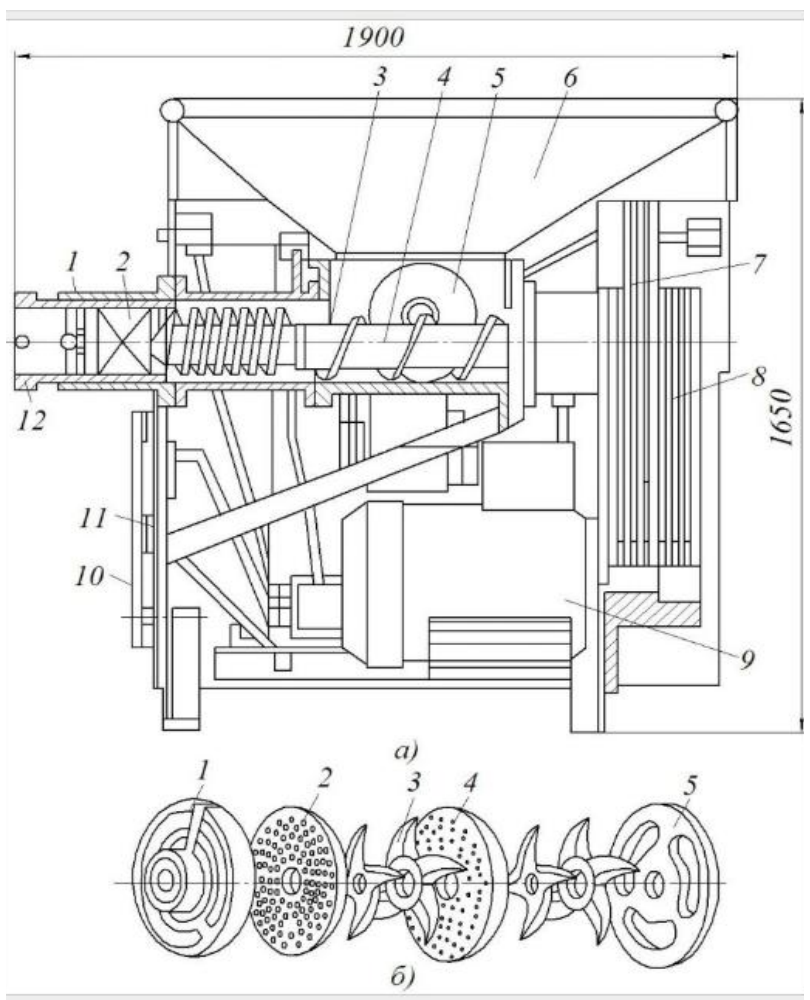

Figure 3- Meat grinder K7-FVP-160-2

The grinder works as follows: trimmed meat in pieces weighing up to $0.5 \mathrm{~kg}$ is fed into the hopper, from where it is picked up by the working and auxiliary augers and sent to the area of the cutting mechanism. In this zone the meat is ground to a defined degree, which is ensured by installing knives and cutter plates with appropriate hole diameters. Technical characteristics of the grinders (without loading devices) are given in Table 4. 
Table 4 - Technical specification of the meat-grinder

\begin{tabular}{|ccc|}
\hline Name of parameter & K6-FVP-120 & K7-FVP-160-2 \\
$\begin{array}{c}\text { Technical } \\
\text { performance }(\mathrm{kg} / \mathrm{h})\end{array}$ & 2500 & 5000 \\
\hline $\begin{array}{c}\text { Outer diameter of the } \\
\text { cutter plate }(\mathrm{mm})\end{array}$ & 120 & 160 \\
\hline $\begin{array}{c}\text { Motorpower }(\mathrm{kW}) \\
\text { Overall dimensions, } \\
\mathrm{mm}\end{array}$ & 12.5 & 32.2 \\
\hline Weight, kg, nomore & $8000^{\prime} 1600$ & $1900^{\prime} 1000^{\prime} 1650$ \\
\hline
\end{tabular}

Table 5 - Technical specification of the meat-grinder B-2-114

\begin{tabular}{|cc|}
\hline Nameofparameter & Value \\
\hline Technical performance $(\mathrm{kg} / \mathrm{h})$ & 1000 \\
\hline $\begin{array}{c}\text { Motorpower }(\mathrm{kW}) \\
\text { Outer diameter of the cutter plate } \\
(\mathrm{mm})\end{array}$ & 5.5 \\
\hline Augerrotation speed (rpm) & 114 \\
\hline Number of augers & 220 \\
\hline Meat pieces size (mm) & 1 \\
\hline Overall dimensions (mm) & $150 \times 35 \times 25$ \\
\hline $\begin{array}{c}\text { length } \\
\text { width } \\
\text { height }\end{array}$ & 700 \\
\hline Weight $(\mathrm{kg})$ & 1180 \\
\hline
\end{tabular}

\subsection{The grinder $B-2-114$}

The grinder B-2-114 is designed for grinding boneless trimmed meat, meat cuts, meat and bone by-products and back fat. The product's temperature should be within the limits from $0{ }^{\circ} \mathrm{C}$ to +8 ${ }^{\circ} \mathrm{C}$. Grinder B-2-114 can be used at the enterprises of small capacity for meat processing to produce sausage products (http://meaten.ru/m2c112g113-g2-spinnerv2114.php).

In order to obtain minced meat of different degrees of grinding the grinder B-2-114 is equipped with a set of cutter plates, with hole diameters of 3,5, 9 and $30 \mathrm{~mm}$, the input plate and two doublesided cross knives (the product is completed with two sets of cutting tools).

Receiving hopper is made of stainless steel and is equipped with a safety grating, preventing the hands of service personnel to access the feed auger during operation. Technical characteristic of the meat-grinder B-2-114 is given in Table 5.

\subsection{Meat-grinder M-50S}

Meat-grinder M-50S (LLC Factory "TorgMash", Russia) is designed for grinding meat and fish in the production of minced meat for various meat and fish dishes in public catering enterprises (canteens, cafes, restaurants), children's institutions and small businesses. The meat grinder (Figure 4) consists of a drive mechanism and a meat grinder attachment (http://www.torgmash.perm.ru/2.

The meat grinder's operation: meat thoroughly separated from bones and cartilage, cut into pieces weighing 50-70 g, is pushed from the tray into the neck of the nozzle-grinder. The rotating

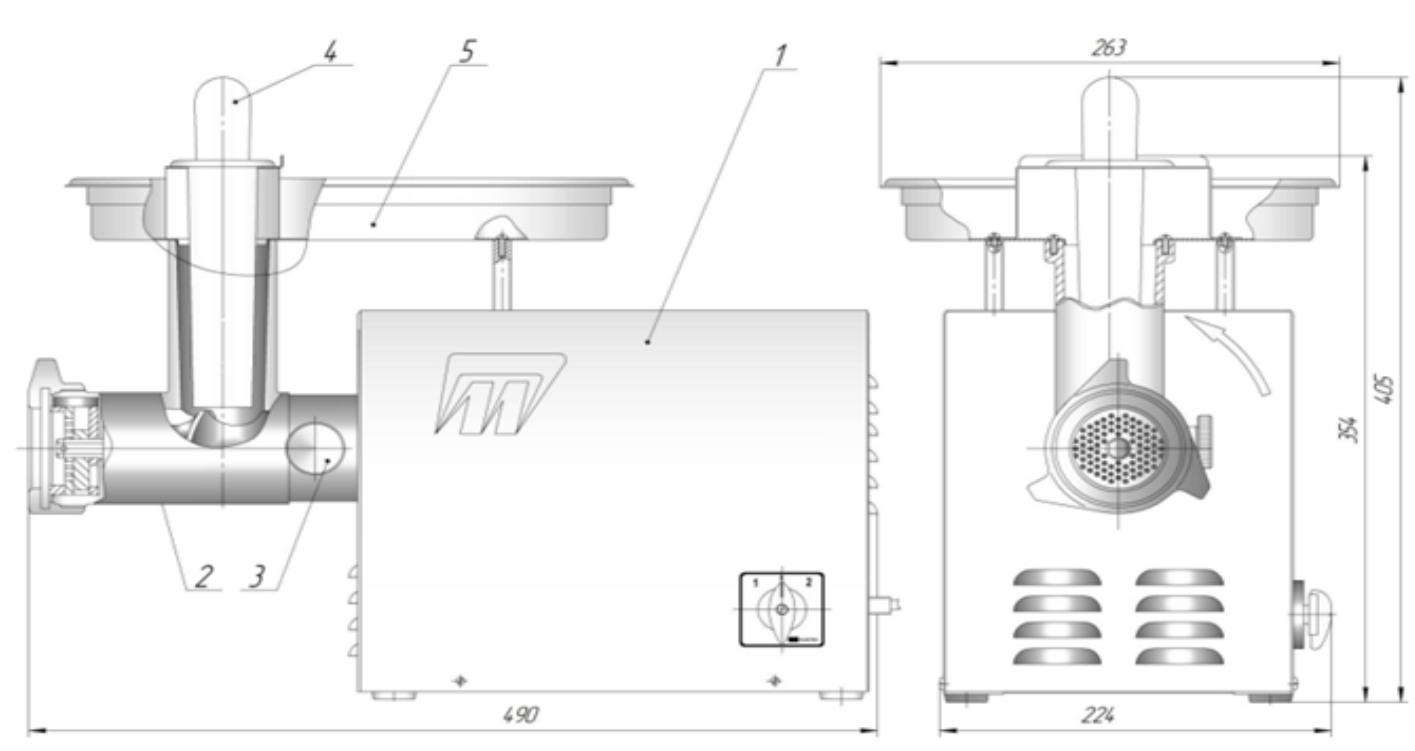

Figure 4 Meat-grinder M-50S: 1 - drive mechanism; 2 - meat grinder attachment; 3 - clamping screw; 4 - pusher; 5 - loading tray

Journal of Experimental Biology and Agricultural Sciences

http://www.jebas.org 
auger grips the meat and feeds it to the undercut plate. The undercut plate cuts the meat and the rotating double-sided knife cuts the meat into smaller pieces. The meat is then pushed through the cutter plate. Technical specification of the meat-grinder M-50 S is shown in Table 6.

Table 6 Technical specification of the meat-grinder M-50 S

\begin{tabular}{|lc|}
\hline \multicolumn{1}{|c|}{ Name of parameter } & Value \\
\hline $\begin{array}{l}\text { Technical performance } \\
\text { (with hole diameter of } \\
\text { cutter plate } \varnothing 5 \mathrm{~mm})(\mathrm{kg} / \mathrm{h})\end{array}$ & $50-80$ \\
\hline $\begin{array}{l}\text { The power supply: } \\
\text { rated voltage }(\mathrm{V}) \\
\text { ratedcurrentfrequency }(\mathrm{Hz})\end{array}$ & 220 \\
\hline Ratedmotorpower $(\mathrm{kW})$ & 50 \\
\hline Augerrotation speed (rpm) & 0.55 \\
\hline Outer diameter of the cutter plate (mm) & 192 \\
\hline Diameter of holes of cutter plate (mm) & 60 \\
\hline $\begin{array}{l}\text { Overall dimensions, mm, no more than } \\
\text { length } \\
\text { width } \\
\text { height } \\
\text { height with pusher }\end{array}$ & $5 ; 9$ \\
\hline Weight, kg, nomore & 500 \\
\hline
\end{tabular}

\section{Conclusion}

The review showed a variety of meat grinders, both in design and technical characteristics. Meat grinders differ in size, cost, functionality and other attributes. The power of the meat grinder varies from $0.55 \mathrm{~kW}$ to $32.5 \mathrm{~kW}$, depending on the household or industrial use.

\section{Conflict of Interest}

Authors would hereby like to declare that there is no conflict of interests that could possibly arise.

\section{Reference}

Akimov MM, Zhamanov HH, Tumenov SN, Mustafayeva AK (2001) Complex experimental studies of the meat grinding process Technique and methodology of experimental investigation. (Analytical review), Semipalatinsk, KazgosINTI, 36s

Bakieva ANAR, Akimov MUKHAMEDZHAN, Abdilova GALIYA, Ibragimov N, Bekeshova G (2019) Developing new type of disk plate for meat chopper and its effect to water-binding capacity and yield stress of minced meat. International Journal of Mechanical and Production Engineering Research and Development 9(6): 377-390.

Elkhina VD, Botov MI (2010) Equipment for catering enterprises. Part 1: Mechanical equipment. Moscow: "Academia" Publishing Center, Pp.416

Kabulov B, Mustafayeva A, Kuderinova N, Kassymov S, Vorobeva A (2019) Effect of mechanical processing of minced meat on the change of yield stress. International Journal of Mechanical and Production Engineering Research and Development 9(5): 333-342.

Kurochkin AA, Lyashenko VV (2001) Technological equipment for animal products processing. - Moscow: Kolos.

Matkin YuL; Sapupokova AV (2010) Modernization of the household electric meat grinder. IzvestiaTulGU. Technical sciences 4(1): 44-49.

Muratzhankyzy N, Kassenov A, Kakimov M, Orynbekov D, Moldabayeva Z, Tokhtarov Z, Yessimbekov Z (2018) Mathematical modeling of the relationship between separation and yield of meat-bone scraps in the pressing process. International Journal of Mechanical Engineering and Technology 9(9): 968-971.

Mustafayeva A, Abdilova G, Akimov M, Yerengaliev A, Muratzhankyzy N, Okuskhanova E (2016) Change of yield stress of minced meat grinded with different kind of cutting mechanism. Research Journal of Pharmaceutical, Biological and Chemical Sciences 7(5): 498-504.

Patent RU 2479352 C1. (2013) Meat grinder. Date of publication.

Uriev NB, Taleisnik MA (1985) Food dispersed systems. Physical and chemical bases of intensification of technological processes. Moscow: Agropromiz dat. Pp. 736.

\section{Online Support}

http://beltorgmash.com/product/myasorubki-mim-300-i-mim-600 http://meaten.ru/m2c112g113-g2-spinnerv2114.php

http://tsib.agroserver.ru/tovari/1025448.htm

http://www.torgmash.perm.ru/

https://euro-pack.ru/volchok-vrd-125a

https://food-mechanics.ru/?p=595

https://www.mobilluck.com.ua/katalog/meat/briz/briz-EMS30_160_M11_04-108767.html 